Louisiana State University

LSU Digital Commons

Faculty Publications

Department of Biological Sciences

$1-8-2007$

\title{
A new species of Ophiomegistus Banks (Acari: Paramegistidae) from Papua New Guinea
}

Hans Klompen

The Ohio State University

Christopher C. Austin

Louisiana State University

Follow this and additional works at: https://digitalcommons.Isu.edu/biosci_pubs

Recommended Citation

Klompen, H., \& Austin, C. (2007). A new species of Ophiomegistus Banks (Acari: Paramegistidae) from Papua New Guinea. Zootaxa (1387), 47-57. https://doi.org/10.11646/zootaxa.1387.1.4

This Article is brought to you for free and open access by the Department of Biological Sciences at LSU Digital Commons. It has been accepted for inclusion in Faculty Publications by an authorized administrator of LSU Digital Commons. For more information, please contact ir@lsu.edu. 


\title{
A new species of Ophiomegistus Banks (Acari: Paramegistidae) from Papua New Guinea
}

\author{
HANS KLOMPEN ${ }^{1} \&$ CHRISTOPHER C. AUSTIN ${ }^{2}$ \\ ${ }^{1}$ Acarology Laboratory, Dept. of Entomology, Ohio State University, 1315 Kinnear Rd., Columbus, OH 43212. \\ E-mail:klompen.1@osu.edu \\ ${ }^{2}$ Museum of Natural Science, Louisiana State University, 119 Foster Hall, Baton Rouge, LA 70803. E-mail: ccaustin@lsu.edu
}

\begin{abstract}
A new species of Ophiomegistus, O. spectabilis, is described from New Guinea. This represents the 13th species of this genus from New Guinea skinks. A re-evaluation of host and locality data for the genus shows a host range restricted to squamates, especially skinks, but no obvious specificity for individual skink species. Specificity for small geographical areas seems more likely.
\end{abstract}

Key words: reptile parasites, associations, Scincidae

\section{Introduction}

The island of New Guinea has been identified as a megadiverse region (Mittermeier and Mittermeier 1997) with an estimated $5-7 \%$ of the world's biodiversity in an area representing only $0.6 \%$ of the Earth's land area. Despite its importance as a biodiversity hotspot (Mittermeier et al. 1998), the parasites of New Guinea wildlife are poorly studied. One group that appears to have radiated in New Guinea is the mite genus Ophiomegistus (Mesostigmata: Paramegistidae). Species in this genus are unusual among basal Mesostigmata, and even within the family Paramegistidae, by their association with vertebrates rather than with arthropods. Very little is known about their biology. The adults are blood feeding parasites, that live partially lodged under the scales of their hosts, which can be skinks (17 spp. described so far) or snakes (3 spp.) (Domrow 1978, 1984; Goff 1979, 1980a, b; Womersley 1958). Immatures are unknown for the entire genus. Presumably, they live off the host. Biogeographically, the genus is restricted to the Australasian region, but the majority of species (12) has been reported from New Guinea.

A recent collection of skinks from Rambutyo Island (Papua New Guinea) turned up several specimens of a new Ophiomegistus species collected from several individuals of Sphenomorphus pratti (Scincidae). The purpose of this paper is to describe this species and to review existing records.

\section{Material and methods}

Lizards were captured by hand and inspected for parasites. Ectoparasites were placed into a $2.0 \mathrm{~mL}$ vial with 90\% ethanol for later examination. Lizard specimens were vouchered and deposited at the Louisiana State University Museum of Zoology (LSUMZ).

Mite specimens were cleared and slide mounted. Pencil drawings were prepared using a Zeiss Axioskop ${ }^{\circledR}$ 
equipped with a drawing tube. Resulting images were scanned and redrawn in Adobe Illustrator ${ }^{\circledR}$ (Adobe Systems Inc., San Jose). All measurements are in micrometer $(\mu \mathrm{m})$ in the format: average (range). Palpal chaetotaxy follows Evans (1963b), leg chaetotaxy follows Evans (1963a; 1965; 1969).

\section{Ophiomegistus spectabilis Klompen \& Austin sp. nov.}

(Figs. 1-5)

Diagnosis. Female with two small setae on each latigynial shield. Ventral opisthosoma of both adults with a few very small setiform setae anterior on the ventri-anal shield and 15-22 large, translucent, leaf-like setae covering most of the posterior parts of that shield. Metapodal shields broadly fused with peritrematal shields. Marginal setae well developed, including long rod-like setae interspersed among larger numbers of distinctly shorter, rounded, and blade-like setae.

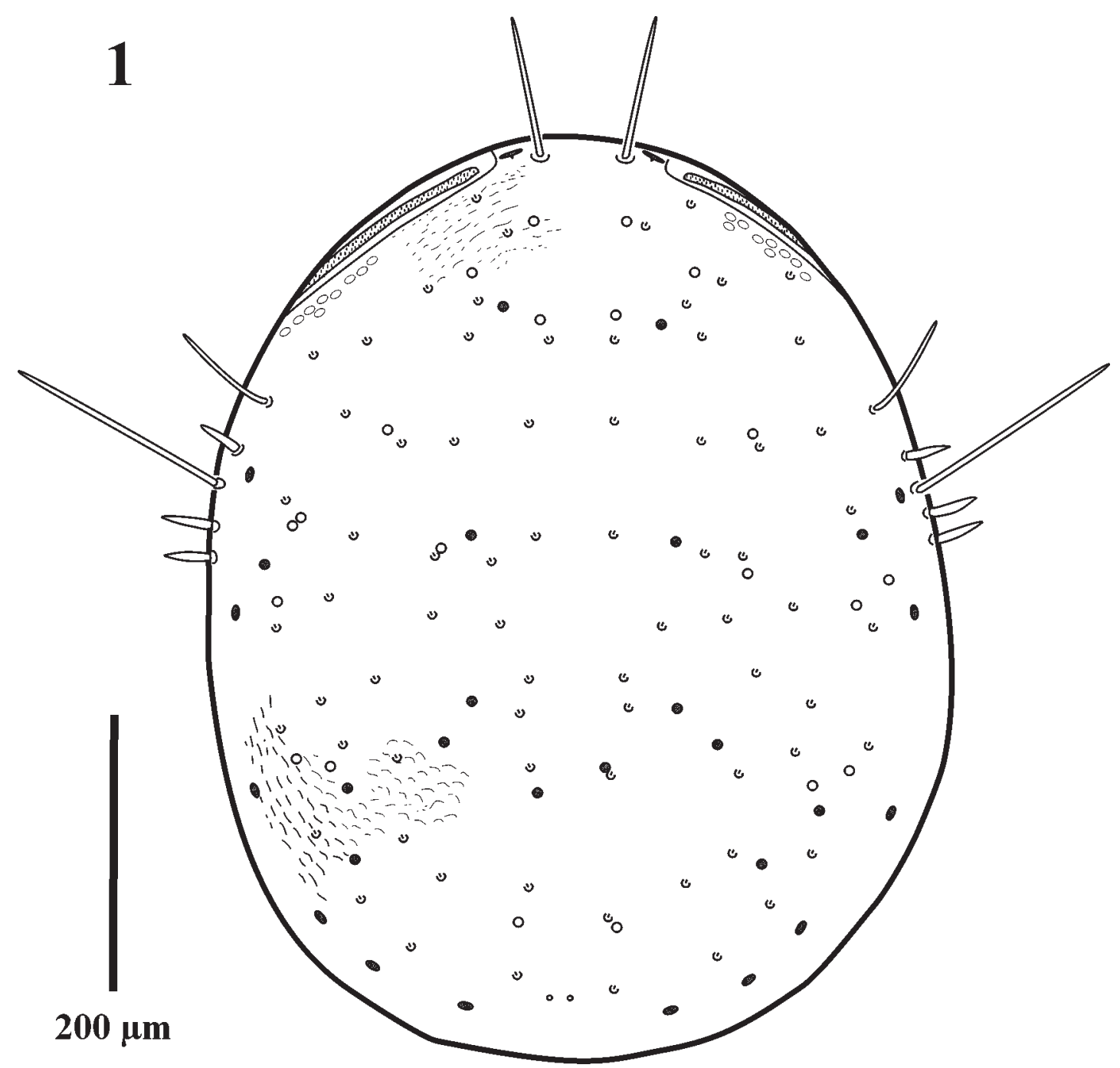

FIGURE 1. Ophiomegistus spectabilis sp. nov. (male). Dorsum. Open circles: presumed glands; filled circles: presumed lyrifissures.

Male (Figs. 1-4). Idiosomal length 741 (681-767), width 604 (568-640), N=5. Dorsum covered by a single shield with slightly crenulate patterning (Fig. 1); pattern more of less striate near the margin, uniform in the center of the shield. One pair of anterior marginal setae (j1?) long (108 [90-118]) and rod-like with small 
barbs near the tip; other dorsal setae minute. Setal patterns are not completely regular and symmetrical, but hypertrichy appears limited; nearly all setae observed can be accommodated within the standard model for Mesostigmata (Lindquist and Evans 1965). With respect to other cuticular structures (glands, lyrifissures) assignment is tentative, due to the difficulty of distinguishing consistently between gland-like structures and lyrifissures (only anterior lyrifissure $i d l$ is quite distinct). Even so, the patterns appear generally symmetrical and surprisingly regular. Specialized marginal setae ( $R$ and $R v$ setae?) surround the entire opisthosoma. They include two types of setae, long, rod-like ones and much shorter, blade-like setae with rounded tips. The rodlike setae are generally smooth, with a few very small barbs near the tip, the blade-like setae have rounded tips and are somewhat flattened. The total number and interspersion pattern of these setae is variable between individuals and even between the left and right side of single individuals (Table 1). Lateral blade-like setae smaller than the posterior ones, with the median posterior pair longest [84 (73-90)]. Most rod-like setae of similar size, 231 (211-250) for posterior lateral ones, but the most anterior lateral pair of rod-like setae much shorter [94 (81-102)], and the pair flanking the median posterior pair of blade-like setae somewhat shorter [167 (150-184)].

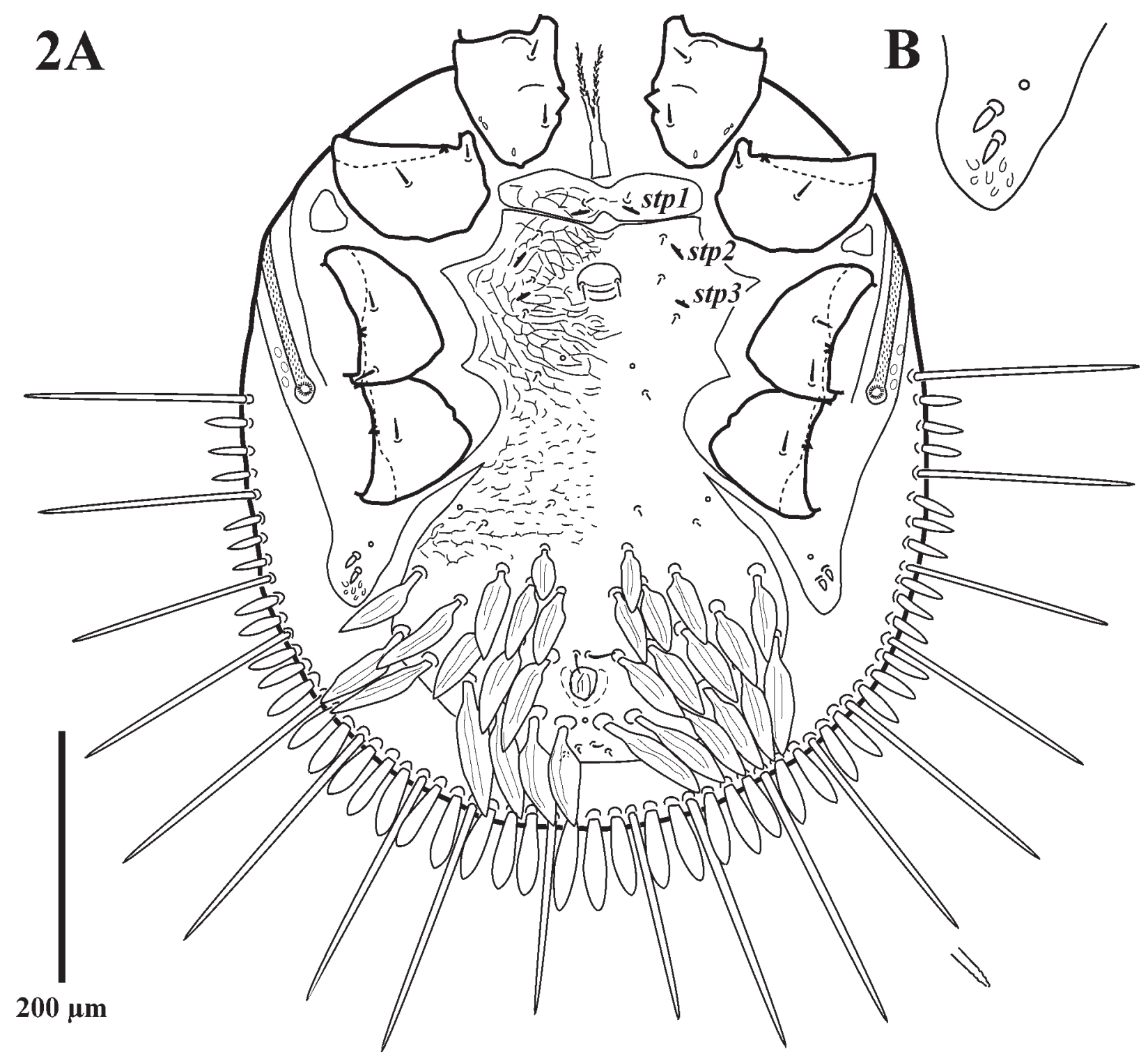

FIGURE 2. Ophiomegistus spectabilis sp. nov. (male). A, venter; B, detail metapodal area. 
TABLE 1. Individual variability in pattern of marginal setae for Ophiomegistus spectabilis sp. nov. Format: number of short, blade-like setae between long, rod-like setae; listing following margin starting anterior left side to right side; posterior median group in brackets.

\begin{tabular}{llll}
\hline Individual & pattern & total blade-like & total rod-like. \\
\hline Male & & 51 & 23 \\
OSAL4135 & $1-2-3-3-2-3-2-3-2-3-(3)-2-3-2-2-3-3-3-3-2-1$ & 45 & 24 \\
OSAL4137 & $1-2-2-3-2-3-1-1-3-1-3-(2)-2-2-2-2-2-2-4-2-2-1$ & 45 & 25 \\
OSAL4138 & $1-2-2-3-2-2-2-1-2-2-2-(1)-2-2-2-2-2-2-3-2-3-2-1$ & 43 & 22 \\
OSAL4586a & $1-2-2-3-2-2-2-2-2-2-(2)-2-2-2-2-3-4-3-2-1$ & & 23 \\
Female & & 50 & \\
OSAL4136 & $1-2-3-3-3-3-2-2-2-3-2-(2)-2-2-2-1-2-3-4-4-1-1$ & & \\
\hline
\end{tabular}

Venter (Fig. 2) with a distinct anterior sclerite carrying sternal setae st 1 and one pair of lyrifissures (stp1). Genital opening midsternal, covered by two small shields, and including a pair of small (eu)genital setae. Sternito-ventri-anal shield with pronounced patterning anteriorly, less distinct posteriorly. In the sternal region this shield carries four pairs of small setae, two pairs of lyrifissures (stp2, stp3) and one pair of small pores; two additional pairs of small setae and one pair of pores posterior to coxae IV. Posterior portion of shield with 1519 pairs of large, translucent, and leaf-like setae, arranged in four rows. As with the marginal setae, patterns are variable (Table 2). One pair of small preanal, and two pairs of small postanal setae surround the anus. Unpaired postanal seta absent. Metapodal areas each with well developed shields, fused broadly to peritrematal (anterior), and weakly to sternito-ventri-anal shields (antero-lateral). Each metapodal shield usually with two subulate setae (Fig. 2B); occasionally with one additional, setiform seta (1 of 8 sides examined), or with one subulate and 1 setiform seta ( 3 of 8 sides examined). Metapodal shield surface with distinct crenulated patterning near the posterior tip. Peritremes surrounded by relatively small shields, extending anteriorly to the level of coxae I. Tritosternum without subapical spines (Goff 1979) on the tritosternal laciniae.

TABLE 2. Individual variability in pattern of opisthogastral leaf-like setae for Ophiomegistus spectabilis sp. nov. Format: row 1 (most anterior), row 2, row 3, row 4.

\begin{tabular}{lll}
\hline Individual & right & left \\
\hline Male & $1-3-5-6$ & $1-3-5-6$ \\
OSAL4135 & $1-2(3)-5-6$ & $1-4-6-6$ \\
OSAL4137 & $1-3-5-6$ & $1-3-5-6$ \\
OSAL4138 & $1-3-5-6$ & $1-3-5-6$ \\
OSAL4586a & $1-3-6-6$ & $1-4-5-5$ \\
OSAL4586b & & \\
Female & $1-4-7-8$ & $1-5-6-7$ \\
OSAL4136 & & \\
\hline
\end{tabular}

Gnathosoma and palps (Fig. 3). Chelicera (Fig. 3A) with long cheliceral seta, and distinct lyrifissue $i \propto$, lyrifissure id not observed. Cheliceral digits edentate, inside movable digit fimbriate. Fixed digit with one basal, movable digit with three terminal extensions; interdigital membranous extension present. Gnathotectum triangular with a smooth anterior edge and a very weakly developed, or absent, keel (Fig. 3B). Subcapitulum with a poorly developed deutosternal groove. Subcapitular setae $(s c)$ and setae hyp2 short blunt spines with minute barbs, setae hyp 1 long, smooth spines, and setae hyp 3 small and setiform (Fig. 3C). Lateral lips fringed on outside, labium and paralaciniae brush-like. Designation of brushy, dorsally inserted structures as "parala- 
ciniae" (pl in Fig 3C) tentative. Corniculi unclear in all specimens examined, apparently largely membranous and with a shape resembling that illustrated for O. luzonensis Banks (Voss 1966) and O. keithi Domrow (Domrow 1978). Palp (Fig. 3D). Palp setation for the basal segments follows the standard pattern for Antennophorina, 2 setae on the trochanter, 5 on the femur, and 7 on the genu. Posterior lateral and posterior dorsal setae on the femur and genu thickened, rod-like and barbed. Tibia and tarsus completely fused, with a total of 24 sensilla, 1 more than listed by Domrow (1978) for O. keithi and O. luzonensis. Pretarsal claw two-tined.

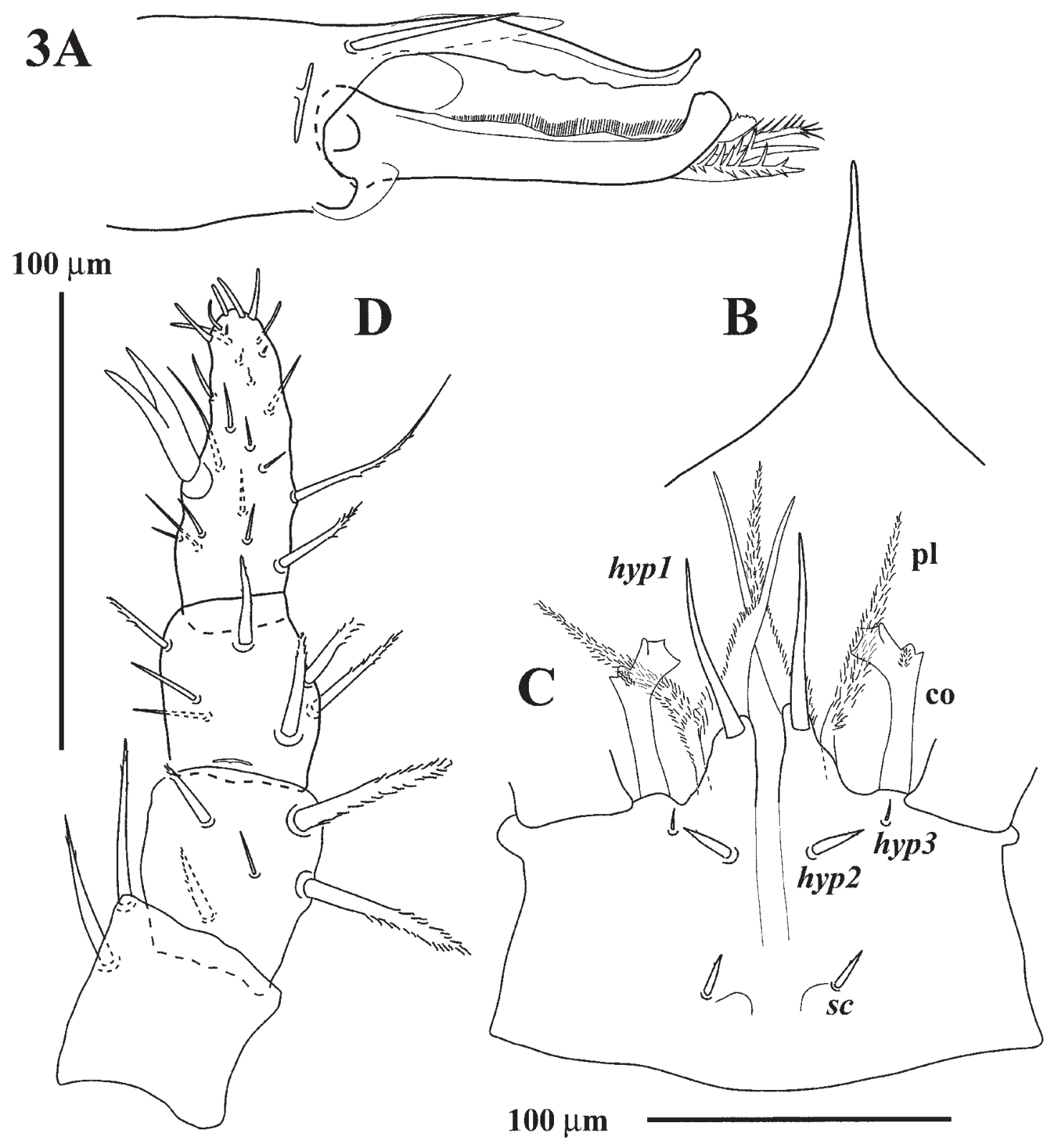

FIGURE 3. Ophiomegistus spectabilis sp. nov. (male). A, chelicera; B, gnathotectum; C, subcapitulum; D, palp, dorsal view. Scale for A, B and D identical. Abbreviations: co, corniculus; pl, paralacinia.

Legs (Fig. 4). Coxae I with small anterior spur (Fig. 2A). Setation pattern generally as for O. luzonensis (Domrow 1978), but without tibial setae $p d 3$ I and $p v 2$ IV, losses shared with $O$. keithi. Legs laterally flattened, most lateral setae poorly developed. Femoral seta $p v 1$ IV a rounded spine. Anterior dorsal setae of genua, tibiae, and (basi)tarsi III-IV blade-like with fimbriations along one side (less prominent on legs II), posterior dorsal and posterior ventral setae generally longer, rod-like with terminal barbs. Genual and tibial setae pll II-III long, rod-like; genual and tibial pll IV small, setiform. Tarsi II-IV with seta al3 present. setae 
$a d 1, p d 1$ poorly developed, very thin. Ventrodistal spurs on tarsi II-IV absent. Pretarsi I absent, pretarsi II-IV large, with vestigial claws. Chaetotactic formula's: Coxae 2-2-2-1. Trochanters I: 2 1/2 1; II: 1 0/3 1; III: 1 1/3 0; IV: 1 1/3 0. Femora I: 2 3/3 1/2 1; II: 2 2/2 2/1 1; III: 1 2/1 2/1 0; IV: 1 2/1 2/1 1. Genua I: 2 3/1 3/1 1; II: 2 3/2 3/1 1; III: 2 3/1 2/1 1; IV: 2 3/1 2/1 0. Tibiae I: 2 2/2 2/2 2; II: 2 2/2 2/1 1; III: 2 2/1 2/1 1; IV: 2 2/1 2/1 1. Tarsi II-III with 19 setae (seta al3 present), tarsi IV with 21 (setae $a v 4, p v 4$ present). Chaetotactic formula's as noted are slightly different from those proposed by Domrow (1978) for O. luzonensis but this may an artifact of leg orientation.

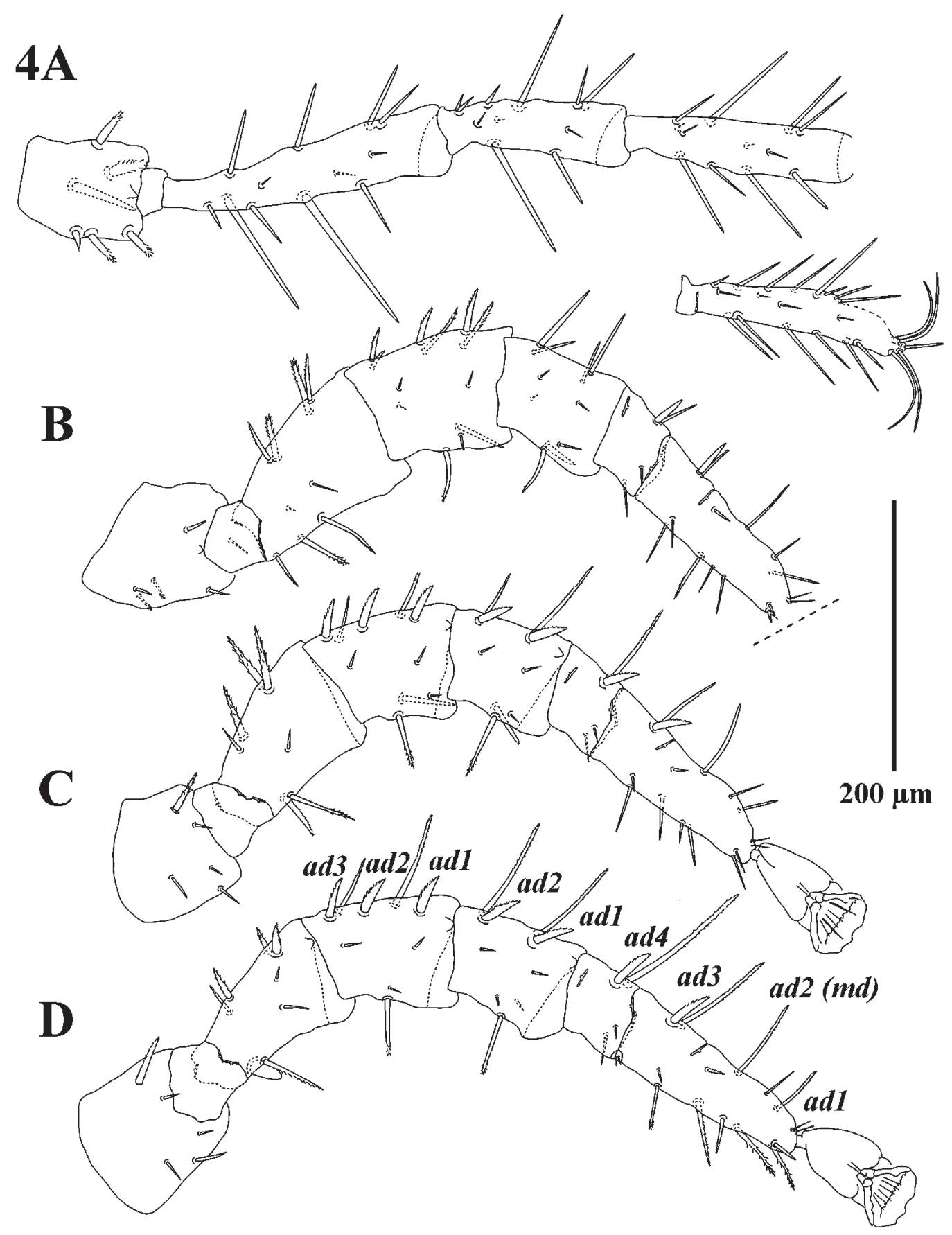

FIGURE 4. Ophiomegistus spectabilis sp. nov. (male). Legs, anterolateral view; A, leg I (setae of distal sensory complex omitted); B, leg II; C, leg III; D, leg IV.

Female (Fig. 5). Idiosomal length 868, width $718(\mathrm{~N}=1)$. Dorsum as in male. Marginal setae slightly more numerous and slightly longer than in male, but pattern very similar (Table 1). Blade-like setae in posterior 
median pair 98 long. Anterior pair of rod-like long setae (j1) 122, anterior lateral pair 113, longest 265, and pair flanking posterior median pair of blade-like setae 197. Peritremes as in male. Metapodal areas sclerotized, shields broadly fused to peritrematal shields (anterior); each with two subulate and one setiform seta (Fig. 5B). Ventri-anal shield with 17-20 pairs of large leaf-like setae, arranged in 4 rows (Table 2). Preanal and postanal setae as in male. Unpaired postanal seta absent. Sternal region anteriorly with two pairs of shields: anterior pair carrying one seta (st l) and one lyrifissure (stp1) each; second pair carrying three pairs of setae (st2-st4) and one lyrifissure (stp2) each. Sternogynial shield also paired, with one small lyrifissure (stp3) on each shield. Genital area with separate and well developed latigynial shields, each carrying two small setae and one small gland pore. Mesogynial shield fused posteriorly with ventri-anal shield, without setae, lyrifissures or pores. Endopodal shield remnants fused to sternal and latigynial shields. Small exopodal shieldlets between coxae II and III.

Gnathosoma and palps. Gnathotectum triangular with a smooth anterior edge. Chelicera as in male. Subcapitulum, corniculi, subcapitular and hypostomal setae as in male. Palp with tibia and tarsus completely fused; pretarsal claw two-tined. Palp setation (number, position, and shape) as in male.

Legs. Leg shape and chaetotaxy as in male.

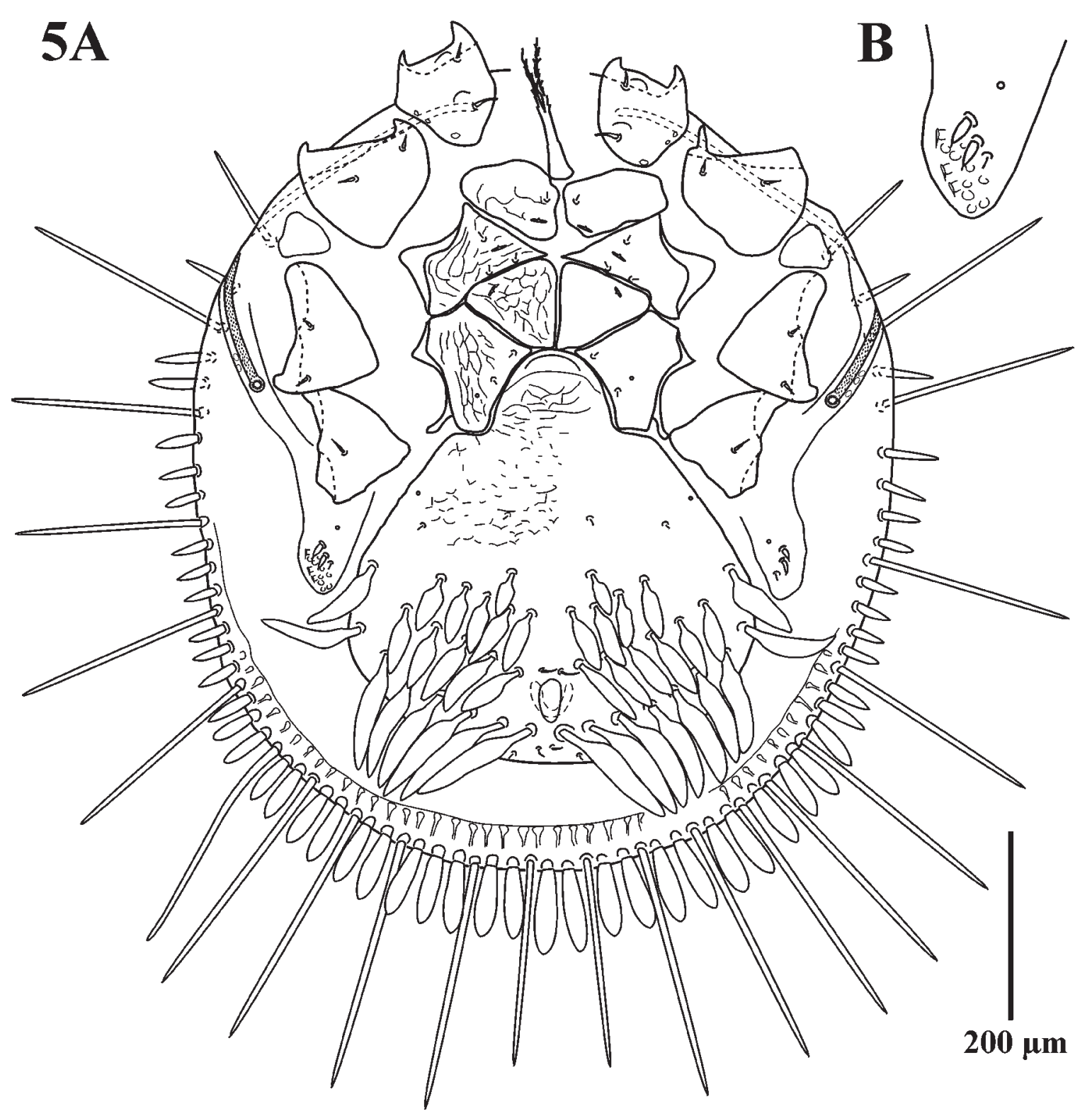

FIGURE 5. Ophiomegistus spectabilis sp. nov. (female). A, dorsum; B, detail metapodal area. 
Material examined. PAPUA NEW GUINEA: Manus, Rambutyo Island, NE of Penchal Village, Elev 100-150 m, 02²0'26"S 147²7'40"E, coll. Austin, C. C., 3 IX 2001, ex Sphenomorphus pratti (Scincidae), host coll. no. LSUMZ 89480, specimens numbers OSAL004135-338 (3M, 1F); same collection data, ex Sphenomorphus pratti, host coll. no. LSUMZ 89481, spec. no. OSAL013822 (1M); PAPUA NEW GUINEA: Manus, Penchal Village, $02^{\circ} 19^{\prime} 42^{\prime \prime S} 147^{\circ} 46^{\prime} 00^{\prime \prime E}$, coll. Austin, C. C., 1 IX 2001, ex Sphenomorphus pratti (Scincidae), host coll. no. LSUMZ 89479, spec. no. OSAL004586 (2M on one slide).

Deposition of types. Holotype male in Ohio State Acarology Collection (OSAL) (OSAL4135), paratypes in Australian National Insect Collection (ANIC), Canberra (2M, OSAL004137-38), and OSAL (1F, OSAL004136, 3M, OSAL004586, 013822).

Etymology. The specific name, spectabilis or showy, refers to the striking pattern of marginal setae in this species.

Systematic affinities. Generic assignment of this species to Ophiomegistus is based on the combination of presence of a longitudinally split sternal shield and stout subulate setae on the posterior end of the metapodal shields. It is also consistent with host association, as all known Ophiomegistus are associated with squamates (snakes or skinks). The one record of $O$. luzonensis from a host other than a squamate, in this case a rat in New Guinea (Gunther 1942), is almost certainly an artifact. In this assignment we noticed a flaw in the latest key to the genera of Paramegistidae (Kim and Klompen 2002). The couplet in that key separating Ophiomegistus from Neomegistus uses the number of setae on each latigynial shield as the primary distinction, with Neomegistus females carrying only two setae per shield, while Ophiomegistus females carry three or more. However, females of O. brachymeleus Voss, 1966, O. mabuyae Voss, 1966, and O. keithi Domrow, 1978 , as well as the female of $O$. spectabilis carry only two setae on each latigynial shield.

That being said, Ophiomegistus can be distinguished from Neomegistus by the presence of foliate setae on the venter (absent in Neomegistus), the lack of fusion of the latigynial and ventri-anal shields (partially fused in Neomegistus) and the presence of subulate setae on the metapodal shields (absent in Neomegistus) (CheolMin Kim, pers. comm.). The above emphasizes that Ophiomegistus and Neomegistus are quite similar, despite being associated with phylogenetically unrelated host groups. This close relationship of squamate (Ophiomegistus) and millipede (Neomegistus) associated taxa mirrors the situation in the family Heterozerconidae, which also includes squamate (Amheterozercon) and millipede (all other genera) associates.

The new species differs from $O$. brachymeleus, O. mabuyae, and $O$. keithi by having the foliate setae restricted to the posterior half of the ventri-anal shield (rather than covering nearly all of the ventri-anal shield). In addition, the striking dimorphism in shape of the marginal setae far exceeds that found in any other described Ophiomegistus species.

Remarks. We also studied two additional females from skinks collected in Milne Bay province (PAPUA NEW GUINEA: Milne Bay, Saga AHO River, Bush Camp, Cloudy Mountains, Elev 65 m, 10³2'39"S 15006'55"E, coll. Austin, C. C., 18 X 2001, ex Sphenomorphus pratti, host coll. no. LSUMZ 89483, spec. no. OSAL004134 (1F); same collection data, ex Sphenomorphus jobiensis, host coll. no. LSUMZ 89482, spec. no. OSAL004133 (1F)). While superficially similar to O. spectabilis in the relative size and arrangement of the marginal and opisthogastral setae, these two females are slightly larger, and differ by having (1) only 3 (not 4) rows of opisthogastral setae, (2) bifid tips on the long rod-like marginal setae (rounded in O. spectabilis), (3) metapodal shields that are distinctly pointed posteriorly, (4) the coxal IV seta shaped as a thick, blunt spine, and (5) having setae hyp2, hyp3, and the subcapitular setae of similar shape (distinctly different sizes in $O$. spectabilis). Given the small number of available specimens from that locality, and the lack of males, it is not possible to establish whether these differences are local variations or whether the specimens represent another new species.

A single male recovered at the same locality but from a different host species (PAPUA NEW GUINEA: Milne Bay, Saga AHO River, Bush Camp, Cloudy Mountains, Elev 65 m, 10³2'39"S 15006'55"E, coll. Austin, C. C., 18 X 2001, ex Sphenomorphus mulleri, host coll. no. LSUMZ 89484, spec. no. OSAL004132), does not match O. spectabilis or the females from Milne Bay. Instead it closely resembles O. kaii Goff, 1979. 


\section{Discussion}

A summary of all published records of Ophiomegistus from New Guinea skinks and snakes is presented in Table 3. This includes updated host and locality data for some previously listed records where individual host collection numbers were cited. Lack of sufficiently detailed information for several records prevented us from resolving all incomplete host and/or locality records. Even with those restrictions, and the limited number of records overall, a few conclusions can be drawn. First, all lizard associated New Guinea Ophiomegistus are associated with skink (family Scincidae) hosts. Skinks represent the world's largest and most morphologically diverse family of lizards. With more than 1227 described species, skinks account for one-third of global lizard diversity (Greer 2001; Zug et al. 2001). Skinks are divided into four major subfamily lineages; Acontinae, Feyliniinae, Lygosominae, and Scincinae (Greer 1979). Of these four subfamilies Lygosomine skinks, the only subfamily occurring in New Guinea, are by far the most diverse and widely distributed. Within the subfamily Lygosominae the Australasian species have been separated into three presumed monophyletic groups, the Egernia, Eugongylus, and Sphenomorphus species groups, each named after a prominent genus in the group (Greer 1979; Greer 1989; Hutchinson 1993). Unambiguous (see Table 3) records of New Guinea Ophiomegistus are from skink hosts in the genera Emoia, Eugongylus, and Sphenomorphus. Emoia and Eugongylus are members of the Eugongylus group and Sphenomorphus is a member of the large Sphenomorphus group. The mite species do not necessarily appear to be specific for a given species, genus, or lineage of skinks. Two out of three species for which more than one record is available were collected from hosts in different genera. However, they may be specific for host ecology or for regions. For example, with the exception of Emoia, all of these skinks are medium to large bodied semi-fossorial lizards that spend considerable time under logs in moist soils and leaf litter. Among the New Guinea snakes from which Ophiomegistus has been recorded, Micropechis ikaheka, is also semi-fossorial. Semi-fossorial habitats are used by a wide range of skinks and other squamates, presenting a wide range of potential host species. This, and the real possibility that geographic ranges for individual Ophiomegistus species may be small, suggests that we can expect to discover many more species in this genus, even on the island of New Guinea.

TABLE 3. Ophiomegistus records from New Guinea snakes and skinks.

\begin{tabular}{|c|c|c|c|}
\hline species & citation record & $\begin{array}{l}\text { host species } \\
\text { coll no. (where known) }\end{array}$ & locality \\
\hline \multirow[t]{7}{*}{ O. luzonensis } & Grant, 1947 & unidentified snake \# & Indonesia, Papua Prov., nr. Jayapura \\
\hline & Domrow, 1978 & Liasis albertisii (Boidae) \# & $\begin{array}{l}\text { Papua New Guinea, Central Prov., Goldie } \\
\text { River }\end{array}$ \\
\hline & Domrow, 1978 & Stegonotus sp.. (Colubridae) \# & $\begin{array}{l}\text { Papua New Guinea, Madang Prov., nr. } \\
\text { Madang }\end{array}$ \\
\hline & Domrow, 1978 & Micropechis sp. (Elapidae)\# & Papua New Guinea, Madang Prov., Madang \\
\hline & Domrow, 1984 & $\begin{array}{l}\text { Micropechis ikaheka (Elapi- } \\
\text { dae) }\end{array}$ & $\begin{array}{l}\text { Papua New Guinea, Morobe Prov. hill S of } \\
\text { Buso, S of Lae }\end{array}$ \\
\hline & & BMNH 1980.534 & \\
\hline & Goff, 1980 & $\begin{array}{l}\text { Emoia caeruleocauda or } \\
\text { Emoia longicauda or } \\
\text { Emoia jakati or } \\
\text { Lipinia noctua or } \\
\text { Lamprolepis smaragdina }\end{array}$ & Papua New Guinea, East Sepik Prov., Dreikkir \\
\hline O. alainae & Goff, 1980 & $\begin{array}{l}\text { Emoia sp. } * \\
\text { E }\end{array}$ & New Guinea \\
\hline
\end{tabular}

to be continued. 
TABLE 3 (continued).

\begin{tabular}{|c|c|c|c|}
\hline species & citation record & $\begin{array}{l}\text { host species } \\
\text { coll no. (where known) }\end{array}$ & locality \\
\hline O. armouri & Goff, 1979 & $\begin{array}{l}\text { Sphenomorphus jobiensis* } \\
\text { BPBM@ }\end{array}$ & New Guinea \\
\hline O. blumi & Domrow, 1984 & Sphenomorphus derooyae * \# & $\begin{array}{l}\text { Indonesia, Papua Prov., Munggona, Eipomak } \\
\text { Valley }\end{array}$ \\
\hline O. iriani & Domrow, 1984 & Emoia pallidiceps $*$ \# & $\begin{array}{l}\text { Indonesia, Papua Prov., Munggona, Eipomak } \\
\text { Valley }\end{array}$ \\
\hline O. joppae & Domrow, 1984 & Carlia fusca or Emoia werneri & $\begin{array}{l}\text { Papua New Guinea, Morobe Prov., nr Buso, S } \\
\text { of Lae }\end{array}$ \\
\hline \multirow[t]{2}{*}{ O. kaii } & Goff, 1979 & $\begin{array}{l}\text { Eugongylus rufescens * BPBM } \\
6097\end{array}$ & Papua New Guinea, Morobe Prov., Kalalo \\
\hline & Goff, 1979 & $\begin{array}{l}\text { Sphenomorphus neuhaussi } \\
\text { ВРВМ } 6095\end{array}$ & Papua New Guinea, Morobe Prov., Kalalo \\
\hline O. nr. kaii & present study & $\begin{array}{l}\text { Sphenomorphus mulleri } \\
\text { LSUMZ } 89484\end{array}$ & $\begin{array}{l}\text { Papua New Guinea, Milne Bay Prov., Sago } \\
\text { River }\end{array}$ \\
\hline \multirow[t]{2}{*}{ O. keithi } & Domrow, 1978 & skink $* \#$ & $\begin{array}{l}\text { Papua New Guinea, East Sepik Prov., Hey- } \\
\text { field, } 8 \mathrm{~km} \text { S Maprik }\end{array}$ \\
\hline & Goff, 1979 & $\begin{array}{l}\text { Sphenomorphus jobiensis } \\
\text { BРВМ } 5732\end{array}$ & $\begin{array}{l}\text { Papua New Guinea, Madang Prov., Wanuma, } \\
\text { Adelbert Mts. }\end{array}$ \\
\hline O. mabuyae & Goff, 1980 & Emoia sp. *\# & New Guinea \\
\hline O. novaguinea & Goff, 1980 & $\begin{array}{l}\text { Sphenomorphus pratti* } \\
\text { BPBM@ }\end{array}$ & New Guinea \\
\hline \multirow[t]{3}{*}{ O. radovskyi } & Goff, 1979 & $\begin{array}{l}\text { Emoia obscura* } \\
\text { BPBM } 5765\end{array}$ & $\begin{array}{l}\text { Papua New Guinea, Madang Prov., Mt. Men- } \\
\text { gam, ca. } 21 \mathrm{~km} \text { NNW of Wanuma }\end{array}$ \\
\hline & Goff, 1979 & $\begin{array}{l}\text { Sphenomorphus derooyae } \\
\text { BPBM } 5762\end{array}$ & $\begin{array}{l}\text { Papua New Guinea, Madang Prov., Mt. Men- } \\
\text { gam, ca. } 21 \mathrm{~km} \text { NNW of Wanuma }\end{array}$ \\
\hline & Goff, 1979 & $\begin{array}{l}\text { Sphenomorphus derooyae } \\
\text { BРВМ } 6096\end{array}$ & Papua New Guinea, Morobe Prov., Kalalo \\
\hline O. samuelsoni & Goff, 1979 & $\begin{array}{l}\text { Eugongylus rufescens * BPBM } \\
2597\end{array}$ & $\begin{array}{l}\text { Papua New Guinea, Morobe Prov., upper } \\
\text { Watut Valley near Bulolo }\end{array}$ \\
\hline O. spectabilis & present study & $\begin{array}{l}\text { Sphenomorphus pratti } * \\
\text { LSUMZ } 89480\end{array}$ & Papua New Guinea, Manus, Rambutyo Island \\
\hline
\end{tabular}

* type host

\# specific host specimen could not be located

(a) probable host specimen located, but not incorporated in collection due to lack of data.

\section{Acknowledgements}

We thank Ilaiah Bigilale and Brank Bonaccorso from the PNG National Museum for their support of field efforts, as well as Barbra Roy, Veari Kula, and Barnabus Wilmott from the PNG Department of Environment and Conservation, and Jim Robins from the PNG National Research Institute. We also thank Lee Goff, Chaminade University, Honolulu, Colin McCarthy, Natural History Museum, London, Alan Resetar, Field Museum of Natural History, Chicago, and especially Carla Kishinami, Bernice P. Bishop Museum, Honolulu, for their help in tracking down host identifications and collection data for previously described species. Thanks to Cheol-Min Kim, University of Connecticut, Storrs, for comments on the paramegistid key. This research was 
funded in part by National Science Foundation grants DEB 0445213 and DBI 0400797 to CCA as well as by a Louisiana State University Faculty Research grant.

\section{References}

Domrow, R. (1978) The genus Ophiomegistus Banks (Acari: Paramegistidae). Journal of the Australian Entomological Society, 17, 113-124.

Domrow, R. (1984) Acari from Operation Drake in New Guinea. 3. Paramegistidae. Acarologia, Paris, 25, 5-16.

Evans, G.O. (1963a) Observations on the chaetotaxy of the legs in free-living Gamasina (Acari: Mesostigmata). Bulletin of the British Museum of Natural History, Zoology, 10, 277-303.

Evans, G.O. (1963b) Some observations on the chaetotaxy of the pedipalps on the Mesostigmata (Acari). Annals and Magazine of Natural History (Ser. 13), 6, 513-527.

Evans, G.O. (1965) The ontogenetic development of the chaetotaxy of the tarsi of legs II-IV in the Antennophorina (Acari: Mesostigmata). Annals and Magazine of Natural History, series 13, 13, 81-83.

Evans, G.O. (1969) Observations on the ontogenetic development of the chaetotaxy of the tarsi of legs II-IV in the Mesostigmata (Acari). In G. O. Evans (Ed.) Proceedings of the 2nd International Congress of Acarology. Akadémiai Kiadó, Budapest, pp. 195-200.

Goff, M.L. (1979) Four new species of Ophiomegistus (Acari: Paramegistidae) from skinks (Lacertilia: Scincidae) in Papua New Guinea, a new record of Ophiomegistus keithi, and a key to the species. Journal of Medical Entomology, $16,512-523$.

Goff, M.L. (1980a) A new species of Ophiomegistus (Acari: Paramegistidae) from a Malaysian kukri snake. Pacific Insects, 22, 380-384.

Goff, M.L. (1980b) The genus Ophiomegistus (Acari: Paramegistidae), with descriptions of five new species, a new structure and a key to the species. Journal of Medical Entomology, 17, 398-410.

Greer, A.E. (1979) A phylogenetic subdivision of Australian skinks. Records of the Australian Museum, 32, $339-371$.

Greer, A.E. (1989) The biology and evolution of Australian lizards. Surrey Beatty and Sons, Chipping Norton, NSW.

Greer, A.E. (2001) Distribution of maximum snout-vent-length among species of scincid lizards. Journal of Herpetology, 35, 383-395.

Gunther, C.E.M. (1942) New parasitid mites from New Guinea (Acarina: Parasitidae). Proceedings of the Linnean Society of New South Wales, 67, 87-89.

Hutchinson, M. (1993) Family Scincidae. Fauna of Australia. Australian Government Publishing Service, Canberra, pp. 261-279.

Kim, C.-M. \& Klompen, H. (2002) A new genus and species of Paramegistidae (Mesostigmata: Trigynaspida) associated with millipedes from Mexico. Acarologia, Paris, 42, 39-52.

Lindquist, E.E. \& Evans, G.O. (1965) Taxonomic concepts in the Ascidae, with a modified setal nomenclature for the idiosoma of the Gamasina (Acarina: Mesostigmata). Memoirs of the Entomological Society of Canada, 47, 1-64.

Mittermeier, R.A. \& Mittermeier, C.G. (1997) Megadiversity: Earth's biologically wealthiest nations. CEMEX, Mexico City, Mexico.

Mittermeier, R.A., Myers, N., Thomsen, J.B., da Fonseca, G.A.B. \& Olivieri, S. (1998) Biodiversity hotspots and major tropical areas: approaches to setting conservation priorities. Conservation Biology, 12, 516-520.

Voss, W.J. (1966) Three trigynaspid mites from Philippine reptiles (Acarina: Paramegistidae). Journal of Medical Entomology, 3, 261-268.

Womersley, H. (1958) Some new or little known Mesostigmata (Acarina) from Australia, New Zealand and Malaya. Transactions of the Royal Society of South Australia, 81, 115-130.

Zug, G.R., Vitt, L.J. \& Caldwell, J.P. (2001) Herpetology: An Introductory Biology of Amphibians and Reptiles. Academic Press. 